\title{
Seasonality induced marginality: Vulnerability of wage earners' food and nutrition security in southern Bangladesh
}

\author{
Mohammad Monirul Hasan \\ Department of Economic and Technological Change, Center for Development Research (ZEF), University of Bonn, Bonn, Germany \\ Email address: \\ monir1021@gmail.com \\ To cite this article: \\ Hasan, Mohammad Monirul. Seasonality Induced Marginality: Vulnerability of Wage Earners' Food and Nutrition Security in Southern \\ Bangladesh. American Journal of Agriculture and Forestry, Vol. 2, No. 4, 2014, pp. 121-128. doi: 10.11648/j.ajaf.20140204.14
}

\begin{abstract}
The paper examines the impact of wage-earning occupation in the food and nutrition security of the rural households' which is partly rooted in the process of marginalization due to seasonality. Seasonality is obvious in the nature but it becomes a problem for those individuals who are heavily dependent on it and they don't have any other buffering system to mitigate this shock such as savings, credit and social security. The result depicts that for being a wage-earner in agriculture, the vulnerability of food and nutrition security increases by $9 \%$ to $12.4 \%$ which are statistically significant at $5 \%$ level of significance. Marginalized households face seasonality every year and they lose their valuable assets to mitigate the adverse effect of natural calamities and idiosyncratic shocks. As a result the instrument to mitigate this seasonality becomes scarce and ineffective which results malnutrition and food insecurity. Because whenever the households do not have any other coping strategy, they just skip meals and start starving for the extended periods.
\end{abstract}

Keywords: Seasonality, Marginality, Food and Nutrition Security, Propensity Score Matching, Bangladesh

\section{Introduction}

Seasonality in agriculture is a common phenomenon which is directly related to the consumption smoothening of the rural households. Seasonality arising from agricultural crop cycle is manifested in household consumption through seasonality of income [1][2][4]. Almost $75 \%$ of the annual income of Indian rural households comes in 3 month period [2]. Besides income households consumption level also varies in rural economies [3][4][5]. Seasonality in consumption is largely driven by seasonal variation in income and partly by the inaccessible to credit market [1]. However, non-credit factors such as preferences, labor effort, seasonal variation in prices and precautionary savings motives affect the consumption seasonality [2][4] identified in rural Thailand that the observed seasonality in consumption pattern occurred due to variation in prices which is more acute than the households' inability to use savings or borrowing. According to permanent income hypothesis any change in consumption caused by shocks to income (transitory income) could be smoothed sufficiently by perfect capital market borrowing as the household would try to maximize utility. Household will borrow from market when it has transitory low income and by saving when having transitory high income. Hence the consumption patterns of households are largely determined by the change in permanent income, rather than the change in temporary income [6]. Hence lack of credit could be a potential determinant of seasonal consumption for rural economies [7]. It is well established in the economic literature that credit constraint are more vulnerable to smoothening consumption [8][9][2] and microcredit can help to mitigate the seasonality in consumption by diversifying agricultural income and employment [10]. In an agrarian society, households manage seasonality primarily through consuming their produced goods, self-insurance (utilization of buffer stock) or mutual insurance (through interfamily transfer), relatives' grant or loans and other means which are part of their crop cycle [1]. Any failure of these means could contribute an increase in the severity of seasonal deprivation. Lack of food entitlement resulting from economic and non-economic forces prevent the poor from having access to employment and other form of economic and social security and eventually making them marginalized in the society [11]. The term marginality means "an involuntary position and condition of an 
individual or group at the margins of social, political, economic, ecological, and biophysical systems, that prevent them from access to resources, assets, services, restraining freedom of choice, preventing the development of capabilities, and eventually causing extreme poverty" [12]. These households become marginalized because they have less income to purchase food and hence that reduces their productivity and hence restricts the development of capabilities which eventually make them marginalized.

With regard to the multi-dimensional nature of marginality, concept of marginality can be framed in to two dimensions as societal and spatial marginalization. Earlier framework attributes on human dimensions such as religion, social structure, wealth, culture, political view or ideology in connection with access to resources by individuals and groups. The latter dimension defined based on physical location and distance from centers of development, lying at the edge of or poorly integrated into system. In contrast, the definition of marginality which is considered by this paper has clearly described the multi-dimensionality of the concept using five different dimensions as social, political, economic, ecological, and biophysical dimensions. So if any given individual or a group of society fails the optimum accesses from at least one of the following mainstreams would possibly considered as a marginal or categorized as victim of marginality.

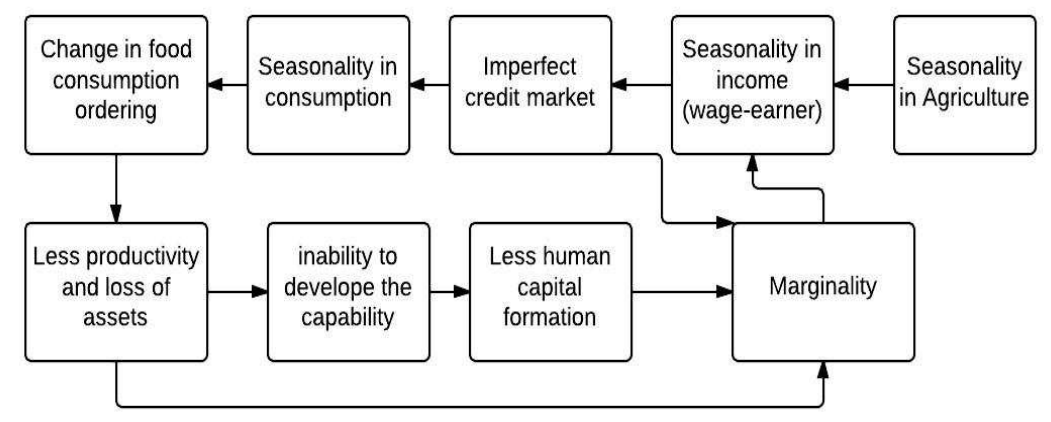

Source: Author's calibration

Figure 1. The economics of marginalization

Figure 1 shows the connection of seasonality and marginality; how one is generated from other one. When there is seasonality in agriculture, agricultural wage earners fall into the seasonality and their income also follow the same trend. But if the wage-earning agricultural worker does not have access to credit market, then seasonality in consumption arises and food consumption level falls for that reason. Less food makes them less productive and less shock absorbing capacity which depletes the assets of the households. The end results translate into marginality which works through the inability develop capability and human capital. Marginality translates into poverty because it restricts the translation of capability into functioning which is the main contribution of Sen, A. [11].

If variation in consumption are only transitory in nature and idiosyncratic across households, interventions such as cash transfer, food coupon and food-for-work can help mitigating seasonality in consumption but if it is because of other factors such as structural poverty arising from low income and productivity then those interventions would be ineffective and unsuccessful.

Household faces credit constraints and credit rationing due to distorted financial markets and principle-agent problems associated with it [13][14]. Hence households consumption is not completely smoothen with the exposer of imperfect financial market [15][16][17]. Households become credit constraints when they are unable to fill the temporary income gap by borrowing sufficiently [14]. Beside the credit constraints households precautionary behavior results the violation of the permanent income hypothesis [18][19][20]. Credit constraint households use personal savings, accumulated assets, external assistance and remittances or cash transfer to absorb the income shocks during lean period. Credit constraint becomes more persistent when they fail to generate sufficient savings for the future [21]. Adverse health shocks increase expenditure and also deplete the savings balance which has a long term impact on welfare [22].

Using the upper poverty line income the national poverty rate is $31.5 \%$ and in Barisal and Khulna region it is $39.4 \%$ and $32.1 \%$ respectively according to Household Income and Expenditure Survey (HIES), 2010. In southern Bangladesh, seasonality varies by rural occupation but there is a trend of seasonal income shock has a pattern to be mentioned. Households' average monthly income continues to fall from April to September and starts to escalate to the benchmark income level of BDT 3000 from September to November. Average income level remains above benchmark level from November to February [23][32].

Food and nutrition security is a major concern of Bangladesh especially in the southern part. According to Food and Agriculture Organization (FAO) food and nutrition Security (FNS) has four pillars- food availability, accessibility, utilization and stability. In this analysis, it is not possible to see the all the outcomes of FNS but focus on some very specific variables. This research is focused on food availability and the accessibility of the households. The short term household level FNS outcome for availability is frequency of meals eaten in a day and for accessibility is food expenditure share on households' total 
budget. About the drivers, the short term FNS drivers are for availability is household size and for accessibility is household dependency ratio, income, distance to nearest market etc. All these can be seen in a table 1 .

Table 1. FNS outcomes and drivers in household level

\begin{tabular}{lll}
\hline & Availability & Accessibility \\
\hline $\begin{array}{l}\text { Outcomes } \\
\text { (Short term) }\end{array}$ & $\begin{array}{l}\text { Number of meals } \\
\text { eaten in a day }\end{array}$ & $\begin{array}{l}\text { food expenditure share on } \\
\text { households total budget } \\
\text { (Short term) }\end{array}$ \\
$\begin{array}{l}\text { Drivers } \\
\text { (Long term) }\end{array}$ & Household size & $\begin{array}{l}\text { Dependency ratio, Income, } \\
\text { distance to nearest market }\end{array}$ \\
\hline
\end{tabular}

Source: Pangaribowo, E. H. et al., 2013[24]

For this paper the outcome variable number of meal consumption eaten in a day will be the basis of analysis.

\section{Data and Methods}

\subsection{Sample}

The study is based on the data of marginalized households of southwestern Bangladesh. Palli Karma Sahayak Foundation (PKSF), Bangladesh introduced a program named PRIME (Programmed Initiatives for Monga Eradication) funded by DFID (Department for International Development), UKaid to eradicate poverty of the rural households in 2011. With the assistance of Partner Organizations (POs) PKSF initially stepped into six Upazilas (sub-district) of three districts in 2011. These districts are Khulna, Patuakhali and Satkhira. Subsequently, the program extended to five more Upazilas by 2012. PKSF conducted a census survey of 60,000 of households (Table 2) and sample for the baseline survey has been taken from this census.

Table 2. Household Covered in the Original Census.

\begin{tabular}{lll}
\hline District & Upazilla & $\begin{array}{l}\text { Total household targeted for } \\
\text { PRIME }\end{array}$ \\
\hline \multirow{2}{*}{ Khulna } & Dacope & 7,588 \\
& Koyra & 13,632 \\
Patuakhali & Golachipa & 13,543 \\
& Kolapara & 5,745 \\
Satkhira & Kaliganj & 11,201 \\
Total & Shaymnagar & 8,344 \\
\hline
\end{tabular}

Source: [23] \& PKSF Household Census for PRIME South.

Criteria for picking marginalized households were as follows- (1) Monthly income less than or equal to BDT 3,000 (Approx. EUR 30) per household during lean season; or (2) Main profession of the household head is daily wage earning (in farming, fishing, logging, honey assortment or other activities); or (3) occupying 50 decimal cultivable land or less.
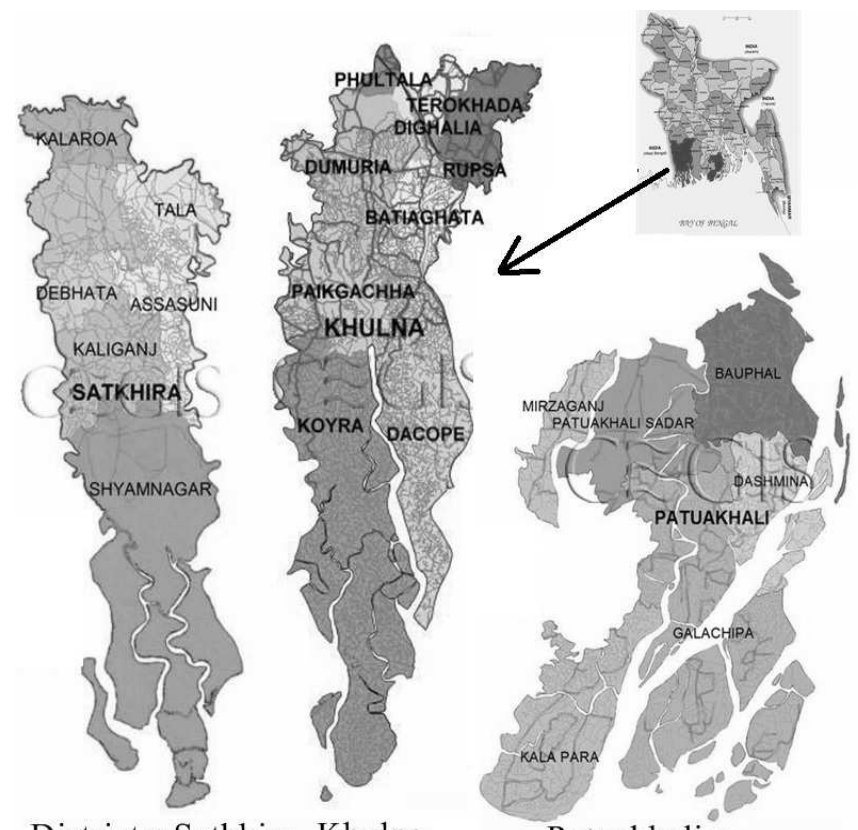

Districts: Satkhira Khulna

Source: Maps are generated by CEGIS. Map of Bangladesh (upper captioned) is from PKSF. [25]

Figure 2. Study area in Southern Bangladesh.

Institute of Microfinance (InM) conducted the baseline survey in 2011 and collected 4000 sample from which 3977 retains. The study area is shown in the figure 2 .

\subsection{Method}

The Propensity Score Matching (PSM) is used for identifying the impact of being wage earner on food consumption vulnerability. The underlying assumption is that selection can be described solely in terms of observable characteristics. For every individual in the treatment group a matching individual is found to be identical individual in the non-treatment group on the basis of observable characteristics. Then average effect of treatment can be calculated as the average differences in the outcomes of two groups. PSM matches each participant with an identical nonparticipant and then measures the average difference in the outcome variable between the participants and the non-participants [27]. It tries to compare similar propensity scores to get the effect. If there is no match found, households are dropped.

The wage-earning households are considered as treated and the other occupation households are considered as non-treated or controlled.

\section{$y_{i}=$ wage_earner $=\left\{\begin{array}{l}1 \text { if households head's occupation is wage earning } \\ 0 \text { if household head is not wage earner }\end{array}\right.$}

Wage earning household is defined as $y_{1}$ and the other occupation (wage_earning $=0$ ) as $y_{0}$. The objective is to determine the average treatment effect on the treated (ATT). The average treatment effect on the treated is defined as 
$A T T=E\left(y_{1}-y_{O} /\right.$ wage_earning $\left.=1\right)$

$=E\left(y_{1} /\right.$ wage_earning $\left.=1\right)-E\left(y_{0} /\right.$ wage_earning $\left.=0\right)$

The first term of the equation is observable whereas the second term is not observable as it is impossible to observe the same individuals as recipient as well as non-recipient simultaneously. The use of propensity score matching can eliminate this problem to estimate $E\left(y_{0} /\right.$ wage_earning $\left.=0\right)$

In the observational studies estimating ATT arises the problem of non-randomness of the selection of the treatment and control and therefore the estimation of ATT suffers from biasedness. PSM can fix this problem which encapsulates the pre-treatment characteristics of subject into a single index - the propensity score which is then used to generate the matching. PSM reduces the biasedness by comparing two groups based on observable characteristics. The validity of PSM depends on two conditions- (1) conditional independence (unobserved factors don't affect participation) and (2) sizable common support or overlap in propensity score across the participant and non-participants.

Any standard model such as Logit or Probit can be applied for estimating the propensity score. For the purpose of estimation Probit model takes the form as follows-

$$
\begin{gathered}
P\left(y_{i}=1 \mid x\right)=P\left(y_{i}^{*}>0 \mid x\right) \\
=p\left(x_{i}^{\prime} \beta+\varepsilon_{i}>0 \mid x\right) \\
=P\left(\varepsilon_{i}>-x_{i}^{\prime} \beta \mid x\right) \\
=1-F\left(-x_{i}^{\prime} \beta\right)
\end{gathered}
$$

Considering the error terms are independently and normally distributed:

$$
\begin{aligned}
P\left(y_{i}=1 \mid x\right)= & 1-\phi\left(-\frac{x_{i}^{l} \beta}{\sigma}\right), \sigma \equiv \mathbb{1} \\
& =\Phi\left(x_{i}^{t} \beta\right)
\end{aligned}
$$

Here $\operatorname{Pr}$ represents probability, and $\Phi$ denotes the Cumulative Distribution Function (CDF) of the standard normal distribution. Parameters $\beta$ are typically estimated by maximum likelihood methods. The usage of the standard normal distribution reasons no loss of generalization compared to using an arbitrary mean and standard deviation as adding a fixed value to the mean can be offset by deducting the same value from intercept and multiplying standard deviation (SD) with a fixed value can be compensated by multiplying the weights by the same value.

Matching participants and non-participants can happen in various ways such as (1) Nearest-neighbor matching, (2) Caliper or radius matching, (3) Stratification or interval matching, (4) Kernel and local linear matching, (5) Difference-in-difference matching etc.

In PSM, the first stage is to determine the propensity score and satisfy the balancing property. The propensity score that is within lowest and highest values for households in the treatment group is called area of common support. With the propensity score generated, the outcome of interest between treatment group and matched control group will be compared. This approach is also used by many authors such as $[28][1][29][30][25][26]$.

\section{Results}

\subsection{Descriptive Analysis}

The descriptive analysis of the selected variables of the households is presented in table 3 . The average age of the household head is 42 years and the years of schooling is 2 . $53.33 \%$ of them are wage-earner and almost most of them are in rural agricultural labors. Almost $10 \%$ works in as self-employed in agriculture and $22 \%$ works as self-employed in non-agriculture. The rate of working outside of home is $13 \%$ who are mostly migrated workers. The average household size is 4 only. Average total land of the household is 13 decimals and of which 5 decimal is for agriculture. Household's yearly income is almost BDT 50,000 in which BDT 40,000 is spent on food and BDT 13,000 is spent on non-food. Households receive average amount of BDT 3,350 as social safety net program from the

\begin{tabular}{|c|c|c|}
\hline Characteristics & Mean & Standard Deviation \\
\hline Age (Years) & 42.6 & 13.8 \\
\hline Years of schooling & 2.0 & 3.1 \\
\hline Wage earner & $53.33 \%$ & $49.90 \%$ \\
\hline Self-employed in agriculture & $9.88 \%$ & $29.85 \%$ \\
\hline Self-employed in non-agriculture & $22.08 \%$ & $41.48 \%$ \\
\hline Live outside the household for work & $12.75 \%$ & $33.36 \%$ \\
\hline Household size (Number) & 4.0 & 1.46 \\
\hline Dependency ratio (female per male) & 1.2 & 0.9 \\
\hline Total owned land (Decimal) & 13.0 & 35.9 \\
\hline Total agricultural land (Decimal) & 4.9 & 27.6 \\
\hline Number of cows & 0.4 & 1.0 \\
\hline Number of goats & 0.6 & 1.5 \\
\hline Number of poultry & 4.0 & 5.5 \\
\hline Asset value including land (Taka) & 58,940 & 123,666 \\
\hline Savings (Taka) & 1,335 & 7,129 \\
\hline Total Income (Taka) & 49,903 & 38,268 \\
\hline Expenditure on food (Taka) & 39,409 & 15,110 \\
\hline Non-foods expenditure (Taka ) & 13,271 & 9,965 \\
\hline Unmet crisis in 2010-11 (Taka) & $1,105.04$ & 5,417 \\
\hline Distance from market place $(\mathrm{km})$. & 3.9 & 2.5 \\
\hline Total formal loan (Taka) & 1,234 & 4,475 \\
\hline Total informal loan (Taka) & 1,643 & 12,216 \\
\hline Social Safety Net received (Taka) & 3,351 & 7,121 \\
\hline Household in char areas & $24.74 \%$ & $43.15 \%$ \\
\hline
\end{tabular}
government. Majority of the households are from mainland but $25 \%$ of the households live in geographically inaccessible areas which is called char areas (river basins) in southern Bangladesh.

Table 3. Summery statistics of the selected variables used in the model

Source: Author's calculation. 
In the southern part of Bangladesh the seasonality of occupations of the households can be observed in figure 3 . The bold black line characterizes the average monthly wage income and the fade straight line characterizes the threshold level of household income at BDT 3,000.

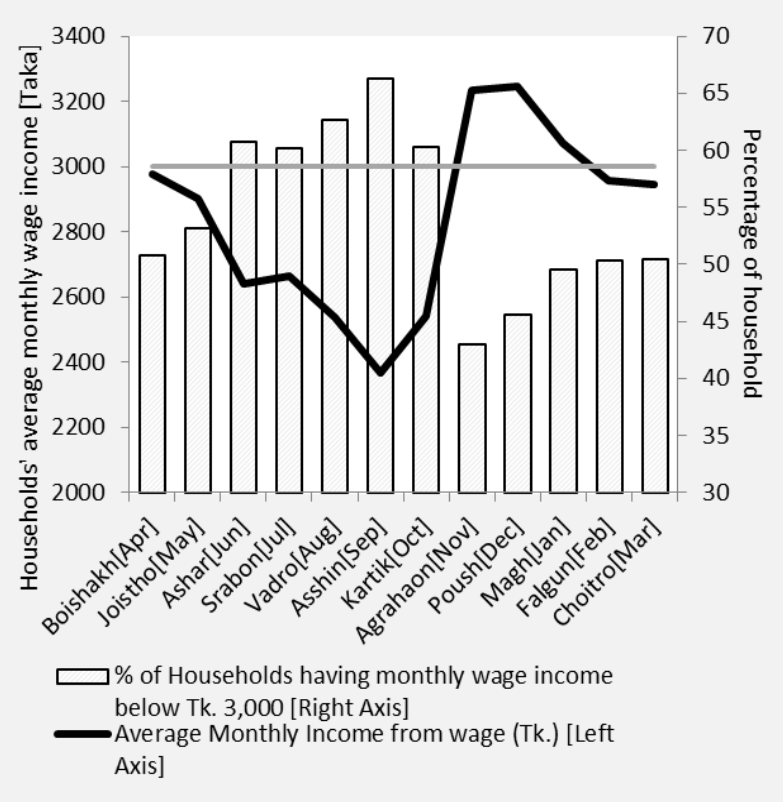

Source: Author's calculation.

Figure 3. Seasonal Dynamics of Households' Monthly income from wage labor.

The shaded bar-diagram characterizes the percentage of households possessing monthly wage income below threshold of BDT 3,000. Average monthly income jumps to fall from Bengali month Boishakh [April] and remains to fall until Asshin [September]. The bar chart of these months is higher than the other months which are the lean season reported by the households. The mean crisis season is 3.5 reported by the households [32]. This season is the monsoon in Bangladesh when the majority of the crop cultivation is hampered by flood.

Afterwards the month of Asshin [September], the wage income starts to rise again new cropping in the field in the beginning of autumn and winter seasons. Farmers start to cultivate and they employed agricultural labor in their fields. Henceforth the wage income flinches to rise until the end of Poush [December]. Once more the wage income starts to decline from Falgun [February] and the similar process repeats every year. In this season of September to February, households make good income (more than BDT $3,000)$ to consume food and non-food expenditure. This can be seen from the bar chart that the percentage of households having monthly wage less than BDT 3,000 is lowest in Agrahaon [November] and it is about 43\% which is lower than the highest $67 \%$ in the month of Asshin [September]. Seasonality is not a problem if they could have savings enough to ensure food security in lean season. But in the study area, the households can't generate enough savings and loans to mark them better off in the lean season.

Households have reported the starting month and the ending month of their food consumption changing pattern. Figure 4 clearly depicts the diverse pattern of starting and ending month of the food insecurity of the households. Over $35 \%$ of the households reported that their deficiencies start on Ashar [June] and 25\% reported it on Asshin [September]. Conversely almost $32 \%$ of the households reported that they end food deficiencies on Kartik [October]. The average length of food insecurity is 3.5 months. From the figure, it can be said that from October to March most of the households end their food insecurity and it starts again from April and continues until September. Albeit households have prior knowledge about this cycle, they can hardly do something against this shock.

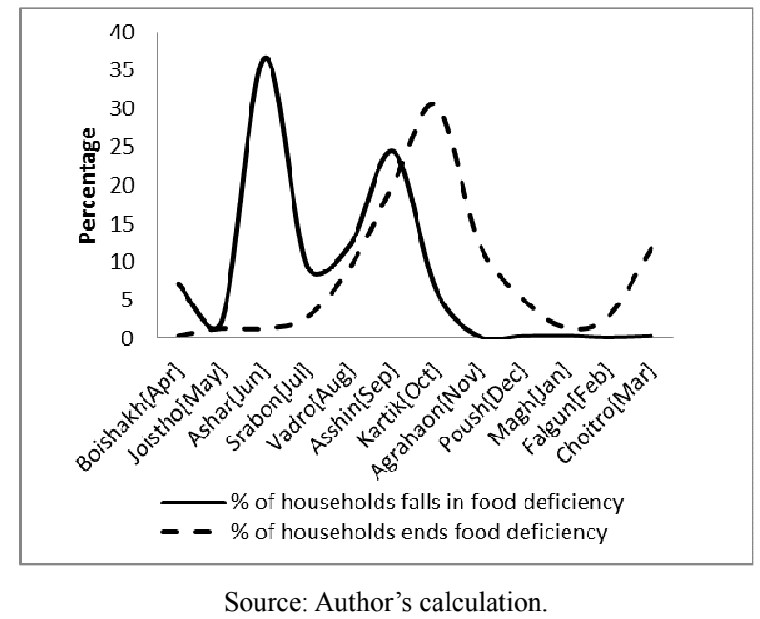

Figure 4. Starting and ending month of households' food insecurity.

\subsection{Households' Food and Nutrition Insecurity}

The main purpose of this study is to examine the food and nutrition insecurity through the meal frequencies. Households described that their food consumption frequencies changes due to the seasonal income shock. Households find themselves capable to buy daily food in normal season but they have to ration their consumption in lean season. Table 4 characterizes the distribution of households having frequencies of food consumption in both normal and lean seasons. It illustrates that in normal time, about $0.28 \%$ of households suffer from occasional starvation, $19 \%$ experience consumption rationing and over $80 \%$ of the households enjoy full 3 meals in a day. But in lean season, around $9.46 \%$ of households fall in occasional starvation, $73 \%$ suffers from consumption rationing and merely $17.46 \%$ can consume full 3 meals in a day. 
Table 4. Transition matrix of households'food and nutrition insecurity.

\begin{tabular}{|c|c|c|c|c|}
\hline \multirow{2}{*}{$\begin{array}{l}\text { Consumption ordering } \\
\text { in normal time }\end{array}$} & \multicolumn{4}{|c|}{ Consumption ordering in lean time } \\
\hline & Occasional Starvation $[<=1$ meal] & Consumption rationing [ 2 meal] & Full 3 meals in a day & Total \\
\hline \multirow{3}{*}{ Occasional Starvation } & 6 & 3 & 2 & 11 \\
\hline & $(54.55)$ & $(27.27)$ & (18.18) & (100) \\
\hline & $(1.62)$ & $(0.1)$ & $(0.29)$ & $(0.28)$ \\
\hline \multirow{3}{*}{ Consumption rationing } & 232 & 508 & 8 & 748 \\
\hline & $(31.02)$ & $(67.91)$ & $(1.07)$ & $(100)$ \\
\hline & $(62.7)$ & $(17.77)$ & $(1.17)$ & (19.12) \\
\hline \multirow{3}{*}{ Full 3 meals in a day } & 132 & 2,348 & 673 & 3,153 \\
\hline & $(4.19)$ & $(74.47)$ & (21.34) & (100) \\
\hline & $(35.68)$ & $(82.13)$ & $(98.54)$ & $(80.6)$ \\
\hline \multirow{3}{*}{ Total } & 370 & 2,859 & 683 & 3,912 \\
\hline & $(9.46)$ & (73.08) & $(17.46)$ & (100) \\
\hline & $(100)$ & $(100)$ & $(100)$ & $(100)$ \\
\hline Pearson $\chi^{2}$ & $<0.01$ & & & \\
\hline
\end{tabular}

Source: Author's calculation, Note: Normal time characterizes when households earn more than BDT 3,000 and lean period characterizes when they earn less than this amount. Values in the parenthesis show row and column percentages.

In Table 4, the dark shaded box denotes the number of households fall in occasional starvation in lean season from normal season. This group of households is vulnerable of degree 2, as the benchmark is full 3 meals in a day. The less dark box embodies vulnerability of degree 1 , because these households degrade one degree level from the benchmark and earlier level. The area from very light shaded box shows the number of households become better off in their declared lean season. They actually enjoy some benefit of seasonality. But the households who gain are very insignificant. The bulk of this group comes from the previous full 3 meals group and they continue it during their lean season indicating they ensure sufficient saving and income source to maintain a consistent consumption frequencies.

The households those were starving occasionally in normal season about $27 \%$ of them switched to consumption rationing and $18 \%$ to full 3 meals category in lean season. But the numbers of households are only 3 and 2 respectively. Conversely, households those who were experiencing rationing their consumption, about $31 \%$ of them fall in occasional starvation, $68 \%$ remain in the same group in lean season. Households who were enjoying full 3 meals in normal season, about $4.19 \%$ of them fall in occasional starvation, $74 \%$ fall in consumption rationing and only $21 \%$ could continue their regular full 3 meals in lean season.

\subsection{Econometric Result}

\subsubsection{Impact of Wage Earning on Vulnerability}

The adverse effect of seasonality in agriculture is higher for the wage-earning households as they are directly involved in this daily labor in agriculture. The paper tries to find the impact of being wage-labor in agriculture on FNS security of the rural households. An econometric technique such as PSM is applied to get the result. Table 5 represents the results of PSM which postulates that for being an agricultural wage-earner the vulnerability of FNS increases by 9 to 12.4 percentage point. There are three matching techniques applied here all of which shows the same trend and statistically significant results. For the nearest neighboring matching, $12.4 \%$ increase in vulnerability whereas in Stratification methods, almost $11.3 \%$ increase in the vulnerability in FNS. In Kernel Matching Methods, it is about $9.2 \%$. So in every matching technique the result seems very robust and statistically significant at $95 \%$ level of confidence interval.

\section{Discussion of Results}

The study of seasonality not scant in the literature and they are also related to the consumption level of households $[1][2][3][4][5]$. But there are very few papers on how seasonality induces the marginality in the literature. Marginality is poorly addressed and there is affluent scope of linking seasonality in marginality. Authors such as [2][3][1] reported about the consumption in aggregate but there is limited number of paper describing the FNS in terms of meal consumption frequencies. The present paper strives to fill the gap by addressing seasonality through marginality and meal consumption frequencies which is one of the outcome variables of FNS. The absence of credit market is highlighted in many papers [8][9][2] as an important interventions advocates the access to credit can improves the situation. But it is not only the absence of credit that restricts them from consumption smoothening but also the right to access the credit. The marginalized households are incapable to accessing credit as they don't fulfill the requirement for getting the credit. So they have problem of availability, accessibility, utilization and stability. Besides, the lack of savings also makes the household food insecure for short term and marginalized in the long term. 
Table 5. Estimation of Average Treatment Effect for the Treated (ATT): Impact of wage-earning occupation on vulnerability in FNS.

\begin{tabular}{lllll}
\hline Matching Methods & Number of treated & Number of control & ATT & Standard Error \\
\hline Nearest Neighbour method & 2023 & 309 & $0.124^{* *}$ & 0.035 \\
Stratification method & 2023 & 468 & $0.113^{* *}$ & 0.048 \\
Kernel Matching method & 2023 & 468 & $0.092^{* *}$ & 0.046 \\
\hline
\end{tabular}

Source: Author's calculation.

Note: $* * * \mathrm{p}<0.01, * * \mathrm{p}<0.05, * \mathrm{p}<0.1$

Like [31] vulnerability in FNS is a transient poverty which is caused by unavailability of physical capital and adverse geographic conditions. Geographic location as well as natural disaster like cyclones can also make them marginalized [25]. Inadequate physical capital obstructs them developing their capabilities along with human capital formation and makes them marginalized. The contribution of this paper is to identify the impact of wage-earning occupation on food and nutrition insecurity of the marginalized households. The result depicts that for being a wage-earner in agriculture, the vulnerability of food and nutrition security increases by $9 \%$ to $12.4 \%$ which are statistically significant at $5 \%$ level of significance. The graphical presentations also support this result because the wide variation in income and food consumption due to seasonality is depicted in figure 3 and figure 4 . It is true that there are other causes which are responsible for the variation in food consumption frequencies but the analysis claims that it is only $9 \%$ to $12.4 \%$ that is caused by the wage-earning occupation.

To identify the impact of occupation on food and nutrition security the problem of selection bias and confounding factor arises. The comparison of treated group and control group becomes questionable and the results they produce become inefficient and inconsistent. To solve this problem of selection bias and endogeneity, propensity score matching technique is used where the treatment group is compared with the control group based on some observable characteristics. The method is widely used to see the impact of any program [27][25] and the sophisticated software tool makes the calculation appropriately.

\section{Conclusion}

From the discussion throughout the paper, it is apparent that there is an impact of wage-earning occupation in the food and nutrition security of the rural households' which is partly rooted in the process of marginalization due to seasonality. Seasonality is obvious in the nature but it becomes a problem for those individuals who are heavily dependent on it and they don't have any other buffering system to mitigate this shock such as savings, credit and social security. Marginalized households face seasonality every year and they lose their valuable assets to mitigate the adverse effect of natural calamities and idiosyncratic shocks. As a result the instrument to mitigate this seasonality becomes scare and ineffective which results malnutrition and food insecurity. Because whenever the households don't have any other coping strategy, they just skip meals and start starving for the extended periods. It is needed to diversify their occupation or income source so that they can smoothen their consumption especially meal consumption and can secure their food and nutrition. The diversification of occupation may occur in various ways. Engagement in non-agricultural wage earning and non-agricultural self-employment can contribute smoothening the food consumption throughout the year. Besides engaging in non-agricultural activities household head can migrate to other places where the job availability is affluent. One possibility is to migrate to cities and do informal jobs. Government and non-government organization can play role to disseminate relevant information for migration and job placement. Various incentive programs such as subsidy for migration, easy loan, money transfer services etc. can motivate individual to migrate or finding new jobs during this seasonally lean period. Different kinds of financial services such as savings, crop insurance and employment guarantee can reduce the shocks arising from seasonality in agriculture.

\section{Acknowledgement}

The study is a part of a Master thesis chapter that was presented and submitted to the Faculty of Business Administration at Corvinus University of Budapest, Hungary \& Faculty of Agriculture, University of Bonn, Germany as in partial fulfilment of the requirements for the degree of Masters of Science. The author is grateful to Professor Dr. Imre Fertő, the first supervisor and Professor Dr. Thomas Heckelei, the second supervisor for their valuable directions. The study was supported by European Union's Erasmus Mundus Program through AFEPA consortium. The author is immensely indebted to Institute of Microfinance (InM) and Palli Karma-Sahayak Foundation (PKSF) for providing data for the study.

\section{References}

[1] Khander, S.R., Khalily, B., and Samad, A., "Vulnerability to seasonal hunger and its mitigation in northwest Bangladesh", Working Paper No. 4, 2010, Institute of Microfinance (InM).

[2] Chaudhuri, S and Paxon, C., "Smoothing consumption under income seasonality: Buffer stock vs. credit." Colombia University, Department of Economics, Discussion paper series, 2001. 
[3] Sahn, D. E., ed. Seasonal Variability in the Thirld World Agriculture: The Consequences for Food Security. Baltimore: Johns Hopkins University Press. 1989.

[4] Paxon, C., "Consumption and Income Seasonality in Thailand", Journal of Political Economy, vol. 101, no. $1: 39-72$

[5] Dercon, S., \& Krishnan, P., "Vulnerability, seasonality and poverty in Ethiopia". Journal of Development Studies, Vol. 366, No. 6:2000, pp 25-53.

[6] Friedman, M., A theory of the consumption functions. Princeton University Press. 1-6, 1957.

[7] Townsend, R. M., "Consumption insurance: An evaluation of risk-bearing systems in low income economies". Journal of Economic Perspectives, 9(3):1995,pp 83-102.

[8] Rosenzweig, M., "Risk, Implicit Contracts and the Family in Rural Areas of Low-income Countries", Economic Journal, Vol. 98, No. 393: 1988, pp1148-1170.

[9] Rosenzweig, M and Wolpin, K., "Credit Market Constraints, Consumption Smoothing and the Accumulation of Durable Production Assets in Low-Income Countries: Investment in Bullocks in India", Journal of Political Economy, vol. 101, No. 2: 1993, pp223-244.

[10] Pitt, M., \& Khandker, S., "Credit programmes for the poor and seasonality in rural Bangladesh". Journal of Development Studies, Vol. 39, No. 2:2001, pp 1-24.

[11] Sen, A., Poverty and Famines: An essay on entitlement and deprivation. Oxford University Press, New York, NY. 1981.

[12] Von Braun, Joachim and Gatzweiler, Franz W., Marginality: Addressing the Nexus of Poverty, Exclusion and Ecology, Springer. 2014

[13] Conning, J., \& Udry, C., "Rural financial markets in developing countries". Handbook of Agricultural Economics, 3, 2007: pp2857-2908.

[14] Morduch, J., "Income smoothing and consumption smoothing." The Journal of Economic Perspectives, 9(3), 1995:pp103-114.

[15] Dercon, S., and Krishnan, P., "Vulnerability, seasonality and poverty in Ethiopia", Journal of Development Studies, Vol. 366 , No. 6, 2000, pp. 25-53.

[16] Duflo, E., \& Udry, C. Intra-household resource allocation in Cote d'Ivoire: Social norms, separate accounts and consumption choices (NBER Working Paper No. w10498).2004.

[17] Goldstein, M. Intrahousehold efficiency and individual insurance in Ghana. London School of Economics Working Paper no.DEDPS38. 2004.

[18] Deaton, A. "Saving and liquidity constraints". Econometrica, 59(5),1991:pp 1221-1248.
[19] Morduch, J., Risk, production and saving: Theory and evidence from Indian households. Harvard University, Manuscript. 1990.

[20] Paxson, C. "Using weather variability to estimate the response of savings to transitory income in Thailand". American Economic Review, 82(1),1992:pp 15-33.

[21] Armendariz, A., and Morduch, J., The economics of microfinance. Cambridge, Massachusetts: The MIT Press. 2005.

[22] Kochar, A. "Explaining household vulnerability to idiosyncratic income shocks". American Economic Review, 85(2), 1995: pp159-1964.

[23] InM, "PRIME intervention in the coastal areas of south-west Bangladesh", Institute of Microfinance (InM), 2011.

[24] Pangaribowo, E. H., Gerber, N. and Torero, M. Food and Nutrition Security Indicators: A Review, Working paper 108, Center for Development Research (ZEF) 2013, Germany.

[25] Hasan, Mohammad Monirul. Climate Change Induced Marginality: Households' Vulnerability in the Meal Consumption Frequencies. American Journal of Environmental Protection. Vol. 3, No. 3, 2014, pp. 103-112. doi: 10.11648/j.ajep.20140303.11

[26] Hasan, M Monirul, "Does credit improve the food consumption vulnerability of the extreme poor? - Empirical evidence from Bangladesh", MPRA Paper No. 28192. 2010. http://mpra.ub.uni-muenchen.de/28192/1/MPRA_paper_281 92.pdf

[27] Khandker, S. R., Koolwal, G.B., and Samad, H. A., Handbook of impact evaluation- quantitative methods and practices. The World Bank. 2010.

[28] Godtland, E., Elisabeth, S., Alain, J., Rinku, M., and Oscar, O., "The impact of farmer- field-schools on knowledge and productivity: A study of potato farmers in the Peruvian Andes", Economic Development and Cultural Change, 52 (1), 2004, pp. 12958.

[29] Heckman, J., Ichimura, H., and Petra T., "Matching as an econometric evaluation estimator", Review of Economic Studies, 65 (2), 1998, pp. 261-94.

[30] Caliendo, M., and Kopeinig, S., "Some practical guidance for the implementation of propensity score matching", Journal of Economic Surveys, 22 (1), 2008, pp. 31-72.

[31] Jalan, J., \& Ravallion, M., "Transient poverty in post-reform rural China", Journal of Comparative, Vol. 26, No. 2:1998, pp338-387.

[32] Hasan, M. Monirul, "Determinants of Food Consumption Vulnerability of the Extreme Poor- Empirical Evidence from Southern Bangladesh", Erasmus Mundus AFEPA 2011-13, University Catholique de Louvain, Belgium. 2013. 